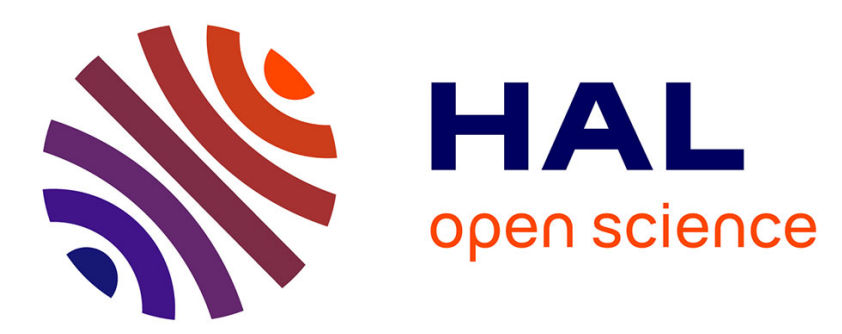

\title{
Several Infra-cranial Non-metric Variations in a Single Neolithic individual: A Common Genetic Underlying Predisposition?
}

\author{
E. Verna, S. Villotte
}

\section{- To cite this version:}

E. Verna, S. Villotte. Several Infra-cranial Non-metric Variations in a Single Neolithic individual: A Common Genetic Underlying Predisposition?. International Journal of Osteoarchaeology, 2016, 26 (6), pp.1113 - 1118. 10.1002/oa.2522 . hal-01500545

\section{HAL Id: hal-01500545 \\ https://hal.science/hal-01500545}

Submitted on 19 Feb 2021

HAL is a multi-disciplinary open access archive for the deposit and dissemination of scientific research documents, whether they are published or not. The documents may come from teaching and research institutions in France or abroad, or from public or private research centers.
L'archive ouverte pluridisciplinaire HAL, est destinée au dépôt et à la diffusion de documents scientifiques de niveau recherche, publiés ou non, émanant des établissements d'enseignement et de recherche français ou étrangers, des laboratoires publics ou privés. 


\section{Several infra-cranial non-metric variations in a single Neolithic individual: A common genetic underlying predisposition?}

\begin{tabular}{|r|l|}
\hline Journal: & International Journal of Osteoarchaeology \\
\hline Manuscript ID & Draft \\
\hline Wiley - Manuscript type: & Short Report \\
\hline Complete List of Authors: & $\begin{array}{l}\text { Verna, Emeline; Aix-Marseille Université/EFS/CNRS, UMR 7268 } \\
\text { Villotte, Sébastien; CNRS, UMR PACEA }\end{array}$ \\
\hline Keywords: & Non-metric variation, genetic etiology, mechanical stress, Neolithic \\
\hline \multicolumn{2}{|l}{} \\
\hline
\end{tabular}




\title{
Several infra-cranial non-metric variations in a single Neolithic individual: A common genetic underlying predisposition?
}

Emeline Verna ${ }^{1}$, Sébastien Villotte ${ }^{2}$

1. UMR 7268 - Anthropologie bio-culturelle, Droit, Ethique et Santé (ADÈS)

Aix-Marseille Université /EFS/CNRS, Marseille, France

2. CNRS, Univ. Bordeaux, MCC, PACEA, UMR5199, Pessac, France

Address

Emeline Verna, UMR 7268 - Anthropologie bio-culturelle, Droit, Ethique et Santé (ADÈS) Faculté de Médecine - Secteur Nord - CS80011 Bd Pierre Dramard, 13344 MARSEILLE Cedex 15, FRANCE

Sébastien Villotte, Anthropologie des Populations Passées et Présentes, UMR 5199 PACEA, Université de Bordeaux - CNRS, Bâtiment B8, Allée Geoffroy Saint Hilaire, CS 50023, 33615 Pessac Cedex, France.

s.villotte@pacea.u-bordeaux1.fr

Correspondence author:

verna.emeline@yahoo.fr

phone: +33491324741

Running title: Several infra-cranial non-metric variations in a Neolithic individual

\section{$\underline{\text { Keywords }}$}

Non-metric variation, genetic etiology, mechanical stress, Neolithic

\begin{abstract}
$\underline{\text { Abstract }}$
Non-metric variations have been the subject of anatomical and anthropological studies for more than a century. In this study, we present an individual from Sion (Canton of Valais, Southern Switzerland) dated from the Middle Neolithic who shows evidence for four nonmetric variations. This young adult male presents an os acromiale, spondylolysis, a bipartite
\end{abstract}


patella and bilateral calcaneus secundarius. These non-metric variations have a low frequency in most populations (less than 10\%) and for each of them the origin is usually considered to be genetic, environmental, or a combination of both. This case is of interest for understanding the potential genetic origin of these non-metric variations as well as for demonstrating their usefulness in bioarcheological analysis.

\section{INTRODUCTION}

Non-metric variations, also called discrete traits, have been the subject of anatomical and anthropological studies for more than a century. These minor non-pathological skeletal variants can be found throughout the human skeleton (Gemmerich Pfister, 1999).

Non-metric variations are commonly used as a measure of biological or genetic distance and variation in archaeological human skeletal samples (e.g. Berry, 1974; Crubézy et al., 1999), although some of them are also considered as activy-related skeletal morphologies (e.g. Stirland, 1987; Villotte et al., 2014). The developmental genetic bases for most of these discrete morphological variants are not well known (Hauser and De Stefano, 1989). A few traits have been studied in humans (Saunders and Popovich, 1978), but most of what is known comes from studies of other primates (for a review see: Wilmore et al., 2012) or mice (Grüneberg, 1952). Genetic, epigenetic (cellular and physiological traits inherited by daughter cells and not caused by changes in the DNA sequence), and environmental factors are probably involved in the appearance of non-metric variations, so a polyfactorial origin could be posited for the appearance of most non-metric variations (Konigsberg, 1993).

In this study, we present a single individual in whom four infra-cranial non-metric variations were observed.

\section{MATERIAL AND METHOD}

The individual presented here come from a necropolis of 25 burials ( 24 single inhumations and one double burial), discovered in 1988 and excavated by Brunier in Sion, at the so-called chemin des Collines (Canton of Valais, Southern Switzerland) (Moinat et al., 2007). Radiocarbon determinations indicate a date for the necropolis of between 4550 and $4100 \mathrm{BC}$, which corresponds to the Middle Neolithic (Moinat et al., 2007).

The non-metric variations were observed and scored as present/absent. The sex of this individual was determined using two methods applied to the ossa coxae (Bruzek, 2002; Murail et al., 2005). Age at death was estimated using the stage of epiphyseal fusion of the bones (Scheuer et al., 2000). 


\section{RESULTS}

The individual is an adult male, around 16-21 years old. The skeleton is in a moderately wellpreserved state. The cranium and mandible and most of the infra-cranial bones are incomplete or fragmentary. Some of the long bones and the left os coxae are complete.

Lumbar vertebrae are poorly preserved but L4 and L5 were identified. L5 presents a spondylolysis (a separation at the pars interarticularis of the neural arch) on the right side (figures 1a, b). The left side is absent. The surface at the separation is smooth and looks like a fibrocartilagineous enthesis (see Boszczyk et al., 2006). L4 does not present any trace of spondylolysis on the right side and the left side is missing. We also observed two inferior articular processes, one right and one left, which presented spondylolysis. The right process corresponds with the body of L5 but it was impossible to associate the left one to the body and the two processes have very different shapes. Thus, this individual presents either: a case of bilateral spondylolysis of L5 with asymmetry of articular processes, unilateral cases of spondylolysis of L4 and L5, or a bilateral spondylolysis of L5 and unilateral spondylolysis of L4.

The individual has an os acromiale on the right scapula (figures 1c, d). Considering the age of the individual it is possible to confuse os acromiale with a normal, unfused acromial epiphysis. However, according to the classifications of Sammarco (2000) and Case et al. (2006), it looks clearly to be an os acromiale with a free, separate fragment and a welldefined articulation: it does not have the appearance of an epiphysis, there is pitting present, and the joint is linear and horizontal to the axis of the acromion. The left scapula is absent. The individual shows a bipartite right patella (figures $2 a, b$ ), the left bone being absent. Only the body of the right patella is present, the bipartite fragment is missing. There is an oblique rupture at the junction between the medial part and the lateral part of the body.

A calcaneus secundarius (a small accessory bone located on the anterior facet of the calcaneus) is present on both calcanei (figures $2 \mathrm{c}, \mathrm{d}$ ), and it is identified via the presence of a notch on the anterior facet.

The four infra-cranial non-metric variations seen in this individual are seen in low frequencies in most contemporary and archaeological populations (table 1). Such a case with several nonmetric variations, each presenting a low frequency is very rare (Saunders, 1978). A study of two French collections shows very few cases and the association of those four traits was not found in any of 295 adult skeletons analysed (table 2) (Verna, 2014). Frequencies for three of 
these non-metric variations ${ }^{1}$ are provided in the table 3 for the Middle Neolithic from Southern Switzerland. None of these variations is especially frequent in this prehistoric sample, and a combination of all of them was not seen apart from the individual presented here.

Apart from these non-metric variations, the skeleton displays only a few other notable features: a metopic suture, shovelling of the upper central incisors, diminutive upper lateral incisors, lateral squatting facets on both tibiae, and a new bone formation on the posterior surface of the left tibia, in the area of the M. soleus attachment site.

\section{DISCUSSION AND CONCLUSIONS}

Mann (1990) examined 1,367 calcanei from several populations. According to him, the origin of calcaneus secundarius is congenital or the result of traumatic injury of the immature calcaneus (i.e. at a cartilaginous stage) resulting in a "pinched off" island of cartilage and an accessory center of ossification. Anderson (1988) suggested that calcaneus secundarius was the consequence of a congenital defect of ossification with mechanical factors causing the separation of the ossicle. An association of calcaneus secundarius, os tibiale externum, and os vesalium, has been reported in one individual in a clinical and radiographic study (Heikel, 1962).

Genetic predisposition has been reported by several authors for the appearance of spondylolysis (Haukipuro et al. 1978; Wynnedavies and Scott 1979), but at the same time the prevalence of spondylolysis seems to be higher in the young athletic population (adolescent and young adult) than in the general population, 15\% for gymnasts for example (Jackson et al., 1976; Goldstein et al., 1991; Soler and Calderon, 2000). Moreover Boszczyk et al. (2006) found that the lysis-zone tissue had an ordered collagenous structure with distinct fibrocartilaginous entheses at both ends, suggesting that compressive and shear forces act at this area.

Stirland (1987) supports a mechanical origin by which the os acromiale results from mechanical strain on the developing acromion, whereas the genetic origin is supported by others (Angel et al., 1987; Sammarco, 2000; Hunt and Bullen, 2007). According to Case et al. (2006) the most likely explanation is a combination of genetic predisposition and high mechanical stresses.

While the cause of a painful bipartite patella is relatively well understood (e.g. Gaheer et al., 2009; Oohashi, 2015), the origin of this variation is not. The patella ossifies from one center in most children, but in ca. $25 \%$ of the population two or three centers are present (Gaheer et 
al., 2009). While this is considered as a normal variant by many authors, some others consider the accessory ossification centre(s) as the result of a disorder of ossification in the primarily cartilaginous formation of the patella due to abnormal stresses produced by excessive action of the inserting musculature during growth (Soren and Waugh, 1994). The ossicle may fuse to the main patellar body (see for instance Anderson, 2002 for an archeological case) or stays unfused. Why the fusion occurs or does not is still not understood (e.g. Soren and Waugh, 1994; Anderson, 2002), but it is likely that genetic predisposition plays a role in some cases (Aloisio, 1961). It is also noteworthy that a case of bipartite patella has been described in association with an autosomal dominant disorder called nail-patella syndrome (Kumar et al., 1999).

Thus, for all these infra-cranial non-metric variations, high mechanical stresses during growth, a genetic predisposition, or a combination of both are evoked to explain their origin. For all of these anatomical areas, authors indicate that fractures due to acute trauma can occur during adulthood, but: 1) they are very uncommon, and 2) usually they can be easily distinguished from the non-union form (e.g. Heikel, 1962; Merbs, 1996; Anderson, 2002; Case et al., 2006). The changes seen in the individual studied here present the "classical" aspect of a non-union, and so do not seem related to acute trauma.

It is possible that this individual performed a range of strenuous physical activities during childhood or adolescence leading to the changes described here. However, even in that case, considering the fact that the four non-metric traits are very similar in their expression (an unattached piece of bone), it seems very likely that this individual was genetically predisposed. Our first conclusion is that in some cases at least, the presence of one of these traits in a single individual or in a sample may be more related to genetic conditions than to mechanical stresses, and thus authors must be cautious before considering these traits in studies of activity-related skeletal morphology. Our second conclusion concerns the relationship between these traits. Indeed, the unique combination of these four non-metric variations, being rare and very similar in their expression, may indicate that a common DNA coding area is involved in their presence.

The systematic research for combinations of these infra-cranial non-metric variations, along with descriptions of other non-metric characteristics that can be associated with a "syndrome" (in the present case possibly the metopic suture, and the diminutive upper lateral incisors) may lead to a better understanding of the underlying genetic control of the expression of these morphological changes in the skeleton. 


\section{Acknowledgements}

We thank Dr. Jocelyne Desideri, anthropologist at the Laboratory of Prehistoric Archaeology and Anthropology at the University of Geneva, who allowed access to the remains; and Christopher Knüsel and Sacha Kacki (PACEA) for their useful comments on the manuscript. The authors declare no conflict of interest.

\section{$\underline{\text { Footnotes }}$}

Presence or absence of calcaneus secundarius was not recorded systematically at the time of the original study on activity-related skeletal morphological changes. So, even if no other case was apparently present, frequencies cannot be calculated. 


\section{REFERENCES}

Aloisio S. 1961. Rotula partita congenita. Considerazioni su tre casi familiari. Acta Orthopaedica Italica 7: 99-104.

Anderson T. 1988. Calcaneus Secundarius: An Osteo-Archaeological Note. American Journal of Physical Anthropology 77(4): 529-531.

Anderson T. 2002. A bipartite patella in a juvenile from a medieval context. International Journal of Osteoarchaeology 12(4): 297-302.

Angel JL, Kelley JO, Parrington M, and Pinter S. 1987. Life stresses of the free blackcommunity as represented by the 1st-african-baptist-church, philadelphia, 1823-1841. American Journal of Physical Anthropology 74(2): 213-229.

Berry A. 1974. The Use of Non-metrical Variations of the Cranium in the Study of Scandinavian Population Movements. American Journal of Physical Anthropology 40(3): 345-358.

Boszczyk BM, Boszczyk AA, Boos W, Korge A, Mayer HM, Putz R, Benjamin M, and Milz S. 2006. An immunohistochemical study of the tissue bridging adult spondylolytic defects - the presence and significance of fibrocartilaginous entheses. European Spine Journal 15(6): 965-971.

Bruzek J. 2002. A method for visual determination of sex, using the human hip bone. American Journal of Physical Anthropology 117(2): 157-168.

Case D, Burnett S, and Nielsen T. 2006. Os acromiale: Population differences and their etiological significance. HOMO-Journal of Comparative Human Biology 57(1): 1-18.

Crubézy É, Telmon N, Sevin A, Picard J, Rougé D, Larrouy G, Braga J, Ludes B, and Murail P. 1999. Microévolution d'une population historique: Etude des caractères discrets d'une population Missiminia (Soudan, III-IVe siècle). Bulletins et Mémoires de la Société d'Anthropologie de Paris 11 (1-2): 1-213.

Gaheer R, Kapoor S, and Rysavy M. 2009. Contemporary Management of Symptomatic Bipartite Patella. Orthopedics 32(11) doi: 10.3928/01477447-20090922-20.

Gemmerich Pfister I. 1999. Création d'une collection anthropologique de référence et application des caractères discrets dans le cas de généalogies connues. Thesis. Université de Genève. $266 \mathrm{p}$.

Goldstein JD, Berger PE, Windler GE, and Jackson DW. 1991. Spine injuries in gymnasts and swimmers - an epidemiologic investigation. American Journal of Sports Medicine 19(5): 463-468.

Grüneberg H. 1952. Genetical studies on the skeleton of the mouse. IV. Quasi-continuous variations. Journal of Genetics 51(1): 95-114.

Haukipuro K, Keranen N, Koivisto E, Lindholm R, Norio R, and Punto L. 1978. Familial occurrence of lumbar spondylolysis and spondylolisthesis. Clinical Genetics 13(6): 471-476.

Hauser G, and De Stefano GF. 1989. Epigenetic variants of the human skull. Lubrecht \& Cramer Ltd: Stuttgart. 301 p.

Heikel HV. 1962. Coalitio calcaneo-navicularis and calcaneus secundarius. A clinical and radiographic study of twenty-three patients. Acta Orthopaedica Scandinavica 32: 72 84. 
Hunt DR, and Bullen L. 2007. The frequency of os acromiale in the Robert J. Terry collection. International Journal of Osteoarchaeology 17(3): 309-317.

Jackson DW, Wiltse LL, and Cirincione RJ. 1976. Spondylolysis in female gymnast. Clinical Orthopaedics and Related Research Jun(117): 68-73.

Konigsberg LW, Kohn LAP, and Cheverud JM. 1993. Cranial Deformation and Nonmetric Trait Variation. American Journal of Physical Anthropology 90(1): 35-48.

Kumar A, Iqbal MJ, and Ali MS. 1999. Separation of bipartite patella in nail-patella syndrome: a case report. The Knee 6(1): 67-69.

Kumar J, Park WH, Kim S-H, Lee HI, and Yoo JC. 2013. The prevalence of os acromiale in Korean patients visiting shoulder clinic. Clinics in orthopedic surgery 5(3): 202-208.

Lawson JP. 1994. Clinically significant radiologic anatomic variants of the skeleton. American Journal of Roentgenology 163(2): 249-255.

Mann RW. 1990. Calcaneus Secundarius: Description and Frequency in Six Skeletal Samples. American Journal of Physical Anthropology 81(1): 17-25.

Masnicova S, and Benus R. 2003. Developmental anomalies in skeletal remains from the Great Moravia and Middle Ages cemeteries at Devin (Slovakia). International Journal of Osteoarchaeology 13(5): 266-274.

Merbs CF. 1989. Spondylolysis: its nature and anthropological significance. International Journal of Anthropology 4(3): 163-169.

Merbs CF. 1996. Spondylolysis and spondylolisthesis: A cost of being an erect biped or a clever adaptation? American Journal of Physical Anthropology, Yearbook of Physical Anthropology 101(S23): 201-228.

Moinat P, Baudais D, and Brunier C. 2007. Les sites de l'avenue Ritz et du chemin des Collines: deux exemples de nécropoles en ville de Sion (Valais, Suisse). In Les cistes de Chamblandes et la place des coffres dans les pratiques funéraires du Néolithique moyen occidental, Moinat P, and Chambon P (eds). Actes du colloque de Lausanne, 12 et 13 mai 2006. Mémoires de la Société Préhistorique Française 43; 277-296.

Murail P, Bruzek J, Houët F, and Cunha E. 2005. DSP: A tool for probabilistic sex diagnosis using worldwide variability in hip-bone measurements. Bulletins et Mémoires de la Société d'Anthropologie de Paris 17(3-4): 167-176.

Oohashi Y. 2015. Developmental anomaly of ossification type patella partita. Knee Surgery, Sports Traumatology, Arthroscopy 23(4): 1071-1076.

Sammarco VJ. 2000. Os acromiale: Frequency, anatomy, and clinical implications. Journal of Bone and Joint Surgery-American Volume 82A(3): 394-400.

Saunders S. 1978. The development and distribution of discontinuous morphological variation of the human infracranial skeleton. Thesis. Toronto University. $549 \mathrm{p}$.

Scheuer L, Black S, and Cunningham C. 2000. Developmental Juvenile Osteology. Academic Press: San Diego. 587 p.

Soler T, and Calderon C. 2000. The prevalence of spondylolysis in the Spanish elite athlete. American Journal of Sports Medicine 28(1): 57-62.

Soren A, and Waugh TR. 1994. Patella partita. Archives of Orthopaedic Trauma and Surgery 113(4): 196-198.

Stewart T. 1953. The age incidence of neural-arch defects in alaskan natives, considered from the standpoint of etiology. The Journal of Bone and Joint Surgery 35(4): 937-950. 
Stirland A. 1987. A possible correlation between os acromiale and occupation in the burials from the Mary Rose. Proceedings of the Vth European Meeting of the Paleopathology Association. Siena; 327-333.

Verna E. 2014. Les variations osseuses asymptomatiques du squelette postcrânien: leur contribution à l'identification en anthropologie médico-légale. Thesis. Aix-Marseille Université. $410 \mathrm{p}$.

Villotte S, Stefanović S, and Knüsel CJ. 2014. External auditory exostoses and aquatic activities during the Mesolithic and the Neolithic in Europe: Results from a large prehistoric sample. Anthropologie LII (1): 73-89.

Wilmore KE, Buikstra JE, Cheverud JM, and Richtsmeier JT. 2012. Developmental Origins of and Covariation Between Metric and Nonmetric Cranial Traits. In Bones, Genetics, and Behavior of Rhesus Macaques, Wang Q (ed). Springer: New York; 61-84.

Wynnedavies R, and Scott JHS. 1979. Inheritance and spondylolisthesis - radiographic family survey. Journal of Bone and Joint Surgery-British Volume 61(3): 301-305. 


\section{$\underline{\text { Legend of figures }}$}

Figure 1: A. Spondylolysis of the fifth lumbar vertebra. B. Articular process of lumbar verterba with spondylolysis. C. Os acromiale on the right scapula. Acromion from the postero-superior view. D. Part of the acromion process with the line indicative of non-fusion.

Figure 2: A. Bipartite right patella. Anterior view. B. Bipartite right patella. Posterior view. C. Calcaneus secundarius on the right calcaneus. Dorsal view. D. Calcaneus secundarius on the right calcaneus. Plantar view. 
Table 1: Frequencies of the four non-metric variations in various current and archaeological populations

\begin{tabular}{|c|c|c|c|c|}
\hline $\begin{array}{c}\text { Non- } \\
\text { metric } \\
\text { variations }\end{array}$ & $\%$ & $\begin{array}{l}\text { Liaison } \\
\text { with sex }\end{array}$ & $\begin{array}{c}\text { Liaison } \\
\text { with } \\
\text { laterality }\end{array}$ & References \\
\hline OA & $0.7-20$ & $\begin{array}{c}M>F \\
\text { North } \\
\text { American }\end{array}$ & $\mathrm{U}>\mathrm{B}, \mathrm{L}>\mathrm{R}$ & $\begin{array}{l}\text { Saunders, 1978; Sammarco, 2000; Case et al., 2005; Hunt and } \\
\text { Bullen, 2007; Kumar et al., 2013; Verna, } 2014\end{array}$ \\
\hline$S$ & $3.2-33$ & $M>F$ & $B>U$ & $\begin{array}{l}\text { Stewart, 1953; Saunders, 1978; Merbs, 1989; Merbs, 1996; } \\
\text { Masnicova and Benus, 2003; Verna, } 2014\end{array}$ \\
\hline BP & $1.4-8.5$ & $M>F$ & - & Saunders, 1978; Lawson, 1994; Anderson, 2002; Verna, 2014 \\
\hline $\mathrm{CS}$ & $1.4-14.3$ & $\begin{array}{c}M>F \\
\text { European }\end{array}$ & $U>B$ & Anderson, 1988; Mann, 1990; Verna, 2014 \\
\hline
\end{tabular}


Table 2: Frequencies and association of the four non-metric variations in two French collections (one contemporary and one from Middle Ages)

\begin{tabular}{ccccc}
\hline \multirow{2}{*}{ Non-metric variations } & \multicolumn{2}{c}{ Olivier } & \multicolumn{2}{c}{ Saint Jean de Todon } \\
& $\mathrm{n} / \mathrm{N}$ & $\%$ & $\mathrm{n} / \mathbf{N}$ & $\%$ \\
\hline OA & $5 / 91$ & 5.5 & $15 / 136$ & 11.0 \\
$\mathrm{~S}$ & $5 / 85$ & 5.9 & $8 / 167$ & 4.8 \\
BP & $7 / 82$ & 8.5 & $1 / 129$ & 0.8 \\
CS & $6 / 63$ & 9.5 & $16 / 121$ & 13.2 \\
OA + S & $0 / 63$ & 0 & $1 / 121$ & 0.8 \\
S + BP & $0 / 63$ & 0 & $0 / 121$ & 0 \\
BP + CS & $1 / 63$ & 1.6 & $0 / 121$ & 0 \\
S + CS & $0 / 63$ & 0 & $1 / 121$ & 0.8 \\
OA + CS & $0 / 63$ & 0 & $3 / 121$ & 2.5 \\
OA + BP & $0 / 63$ & 0 & $0 / 121$ & 0 \\
OA + S + BP & $0 / 63$ & 0 & $0 / 121$ & 0 \\
S + BP + CS & $0 / 63$ & 0 & $0 / 121$ & 0 \\
OA + BP + CS & $0 / 63$ & 0 & $0 / 121$ & 0 \\
CS + S + OA & $0 / 63$ & 0 & $0 / 121$ & 0 \\
OA + S + BP + CS & $0 / 63$ & 0 & $0 / 121$ & 0 \\
\hline
\end{tabular}

n: number of cases, $\mathrm{N}$ : number of individuals for which the present or absence of a trait or of an association can be scored. $\mathrm{OA}=$ os acromiale, $\mathrm{S}=$ spondylolysis, $\mathrm{BP}=$ bipartite patella, $\mathrm{CS}=$ calcaneus secundarius 
Table 3: Frequencies of non-metric variations and associations in the Middle Neolithic sample for Switzerland (73 individuals from Barmaz I, Barmaz II, Chamblandes, Sion Collines, Sion Ritz, Sion St Guerin, St Leonard 4, Corseaux).

\begin{tabular}{ccc}
\hline $\begin{array}{c}\text { Non-metric } \\
\text { variations }\end{array}$ & $\mathrm{n} / \mathrm{N}$ & $\%$ \\
\hline $\mathrm{OA}$ & $2 / 44$ & 4.5 \\
$\mathrm{~S}$ & $4 / 51$ & 7.8 \\
$\mathrm{BP}$ & $2 / 54$ & 3.7 \\
$\mathrm{OA}+\mathrm{BP}$ & $1 / 32$ & 3.1 \\
$\mathrm{OA}+\mathrm{S}$ & $1 / 34$ & 2.9 \\
$\mathrm{~S}+\mathrm{BP}$ & $1 / 38$ & 2.6 \\
$\mathrm{OA}+\mathrm{BP}+\mathrm{S}$ & $1 / 28$ & 3.6 \\
\hline
\end{tabular}

$\mathrm{n}$ : number of cases, N: number of individuals for which the present or absence of a trait or of an association can be scored. $\mathrm{OA}=$ os acromiale, $\mathrm{S}=$ spondylolysis, $\mathrm{BP}=$ bipartite patella. 


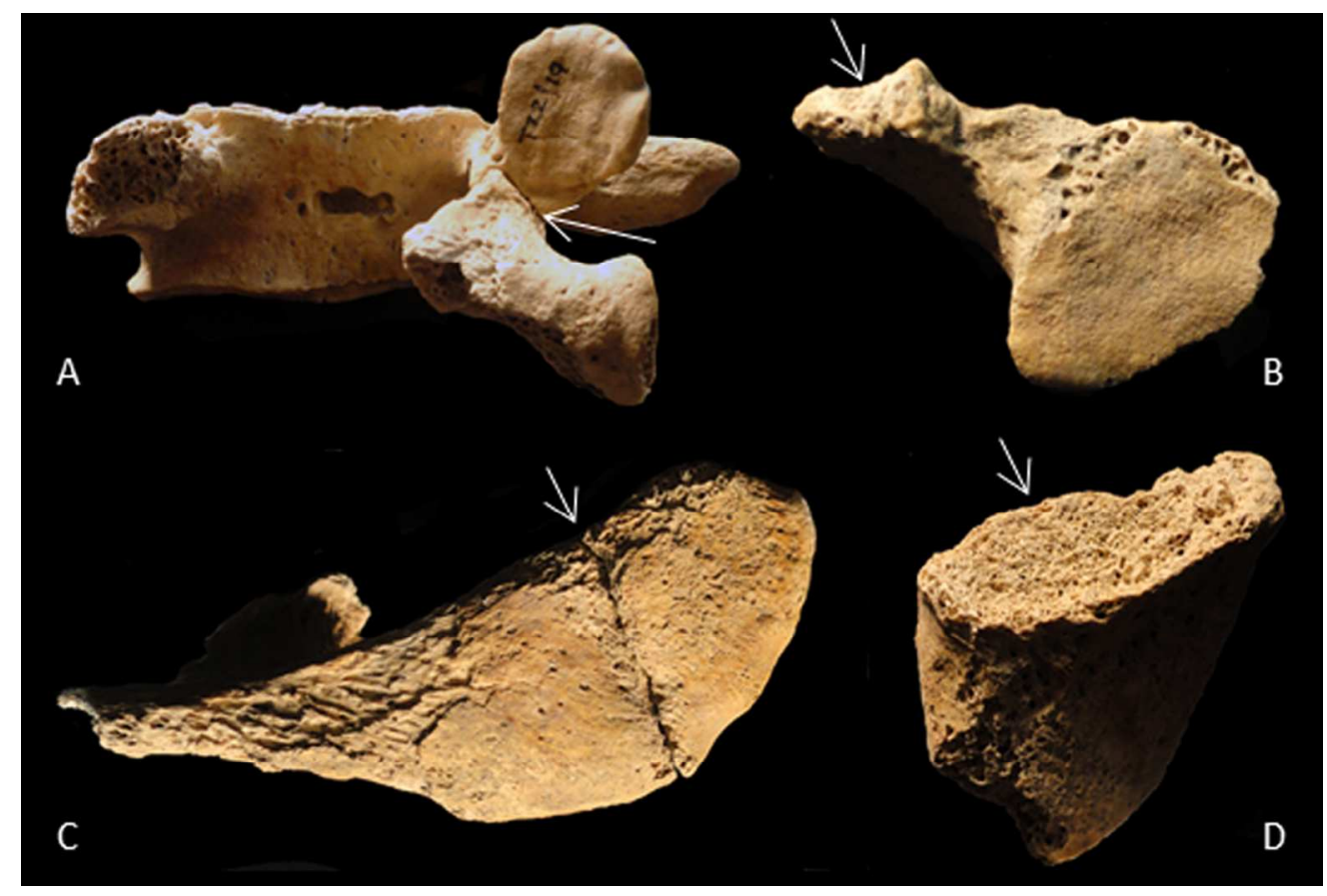

A. Spondylolysis of the fifth lumbar vertebra. B. Articular process of lumbar verterba with spondylolysis. C. Os acromiale on the right scapula. Acromion from the postero-superior view. D. Part of the acromion process with the line indicative of non-fusion. $119 \times 80 \mathrm{~mm}(300 \times 300 \mathrm{DPI})$ 

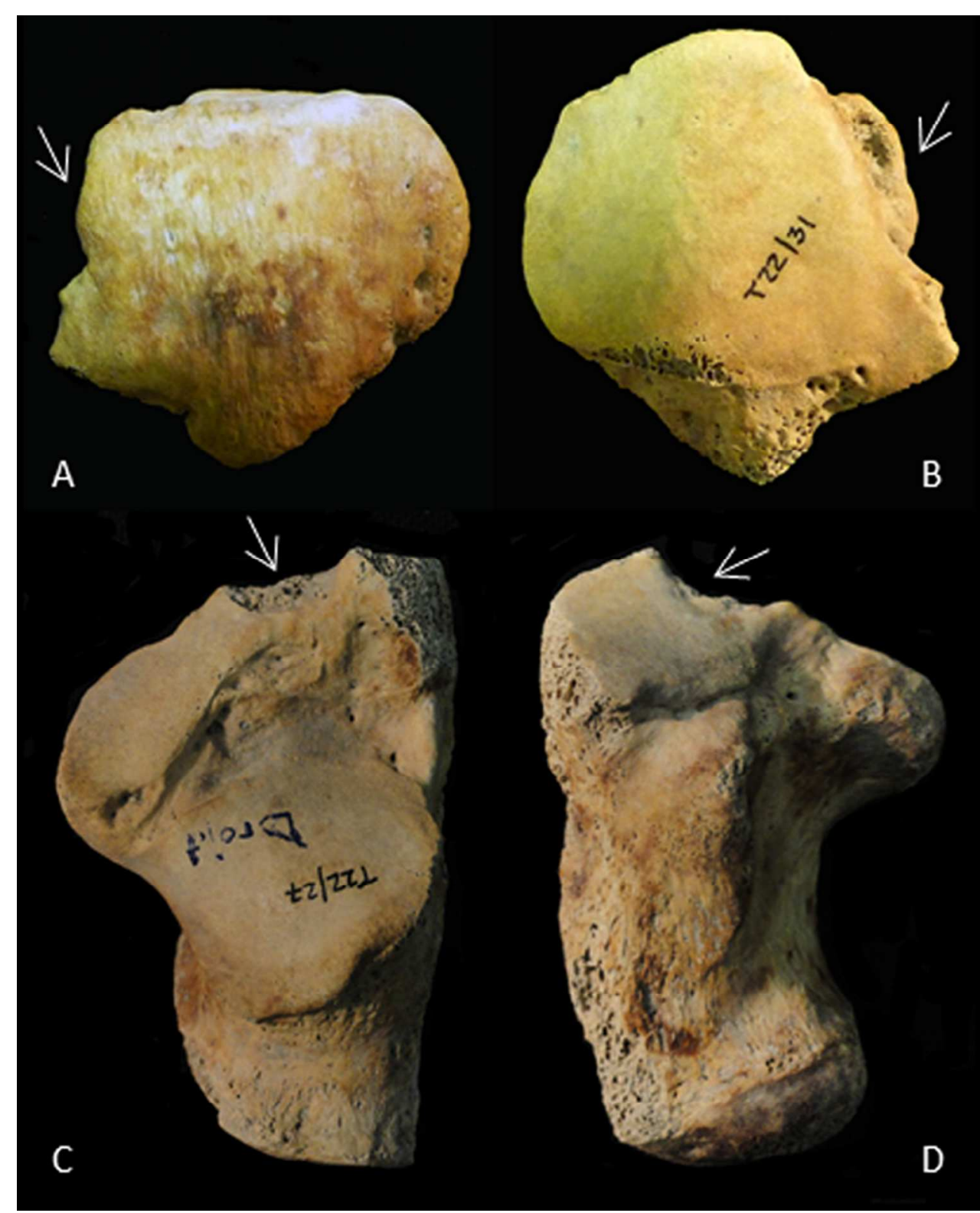

A. Bipartite right patella. Anterior view. B. Bipartite right patella. Posterior view. C. Calcaneus secundarius on the right calcaneus. Dorsal view. D. Calcaneus secundarius on the right calcaneus. Plantar view. $80 \times 99 \mathrm{~mm}(300 \times 300 \mathrm{DPI})$ 